\title{
Postharvest ascorbic acid application maintained physiological and antioxidant responses of Guava (Psidium guajava L.) at ambient storage
}

\author{
Muhammad AZAM ${ }^{1 *}$ (D), Laraib HAMEED ${ }^{1}$, Rashad QADRI ${ }^{1}$, Shaghef EJAZ ${ }^{2}$, Ali ASLAM ${ }^{3}$, \\ Muhammad Imran $\mathrm{KHAN}^{4}$, Jiyuan SHEN ${ }^{5}$, Jiukai ZHANG ${ }^{6}$, Muhammad NAFEES ${ }^{7}$, Ishtiaq $\mathrm{AHMAD}^{7}$, \\ Muhammad Awais GHANI ${ }^{1}$, Jiao $\mathrm{CHEN}^{8}$, Naveeda ANJUM ${ }^{9}$
}

\begin{abstract}
Guava (Psidium guajava) is a highly perishable fruit with a short shelf life as physico-chemical changes occur continuously and rapidly after harvest leading to heavy postharvest losses. This experiment was laid down to unravel the effects of ascorbic acid (AA) on ripened guava fruits to improve its shelf life and quality. Four different concentrations of AA namely 0, 50, 100, $200 \mathrm{ppm}$ were used to treat guava fruit for five minutes followed by storage at $25 \pm 2{ }^{\circ} \mathrm{C}$ and $\geq 80 \%$ relative humidity (RH) for 12 days. Physiological and biochemical changes were studied, together with the specific enzymatic activities for catalase (CAT), superoxide dismutase (SOD) and peroxidase (POD). The results revealed that ascorbic acid treatments significantly reduced $\mathrm{PWL}$, fruit decay percentage and suppressed $\mathrm{pH}$ and sugar/acid ratio than control fruits. Furthermore, soluble solid content, total acidity, total sugar, vitamin $\mathrm{C}$ and total phenolic contents were recorded higher in $200 \mathrm{ppm}$ AA-treated fruits and maintained higher eating quality than control fruits. In addition, SOD, POD and CAT activities were observed higher in $200 \mathrm{ppm}$ AAtreated fruits than control. The results clearly demonstrate that $200 \mathrm{ppm}$ AA application have a potential to improve quality attributes of guava fruit.
\end{abstract}

Keywords: ascorbic acid; biochemical changes; enzyme activities; shelf life; guava.

Practical Application: Application of ascorbic acid improves the quality and shelf life of guava fruit during storage at ambient temperature.

\section{Introduction}

Guava (Psidium guajava L.) is valued fruit crop commercially grown in tropical and sub-tropical zones of world (Watson \& Dallwitz, 1991). The significance of guava is due to its enchanting taste and remarkable nutritional properties as it has five times as much ascorbic acid as citrus fruit (McCook-Russell et al., 2012) and also contains different kinds of essential bioactive compounds (Gutiérrez et al., 2008). Guava has high levels of pectin, dietary fiber, vitamins, antioxidant and mineral contents as compared to the other fruits and, therefore, is used in medicine to cure gastroenteritis, dysentery, healing of wounds and ulcers rheumatics (Olajide et al., 1999).

Guava is climacteric fruit with steep respiration peak and high rate of ethylene production that limits its postharvest shelf-life to three to four days at room temperature whereas, on the other hand refrigerated storage causes chilling injury (Murmu \& Mishra, 2017). Therefore, guava export is limited in the world due to its rapid susceptibility to damages and low shelf life. It has been reported that postharvest losses in guava are higher than pre-harvest losses (Gill et al., 2016). Membrane degradation and browning symptoms are induced by accumulation of reactive oxygen species (ROS) during stress conditions (Mahajan et al., 2017). Previously, various strategies were used to prolong the shelf life of guava such as treatment with edible coatings (Silva et al., 2018), preharvest application of aqueous hexanal (Gill et al., 2016), gamma-irradiation (Pandey et al., 2010), calcium salts (Javed et al., 2016), 1-MCP (Phebe \& Ong, 2010; Xing et al., 2010), control atmosphere storage (Teixeira et al., 2016), low temperature storage (Mahajan et al., 2017) and packaging types (Rana \& Siddiqui, 2018).

Ascorbic acid (AA) is the most abundant antioxidant in nature. AA and its derivates have been used as an antioxidant and anti-browning agent in edible coatings to retain postharvest quality 
of fresh-cut fruits and vegetables (Tapia et al., 2008; Xing et al., 2010). AA in combination with calcium salts and organic acids prevent browning and membrane breakdown by controlling the activity of polyphenol oxidase (Oms-Oliu et al., 2010). AA has also shown antibacterial properties for fresh-cut banana (Yurdugül, 2016), apple (Qi et al., 2011) and papaya (Tapia et al., 2008). Mostly, AA and its derivates have been used as anti-oxidative, anti-browning and antibacterial agent (Sogvar et al., 2016). However, effect of AA on postharvest quality attributes and responses of antioxidant system of guava during ambient storage have not been explored yet. Therefore, this experiment was proposed with the aim to reveal how ascorbic acid effect on physiochemical changes, quality attributes, and antioxidative enzymatic activity in guava cultivar "Golla "during ambient storage.

\section{Materials and methods}

\subsection{Collection Fruit Sample}

Guava fruits (cv. Golla) were freshly harvested from Postgraduate Agriculture Research Station (PARS), Faisalabad, during the month of November and promptly shifted to the laboratory for analysis. Selected fruits were uniform in size, color and maturity stage. Healthy fruits were sorted based on visible symptoms of defect, decay or disease. The solution was prepared by dissolving ascorbic acid (99\%, Sigma-Aldrich, USA) in deionized water. Four different concentrations of ascorbic acid were prepared viz. 0, 50, 100, $200 \mathrm{ppm}$. The selected fruits were washed, dried and dipped in respective ascorbic acid solutions for five minutes. Fruits were air dried before storing at ambient temperature $\left(25 \pm 2{ }^{\circ} \mathrm{C}\right)$ and $\geq 80 \% \mathrm{RH}$. The experimental design was completely randomized design along with factorial arrangements and consisted of four treatments (i.e. 0, 50, 100, 200 ppm AA) with three replications. Each treatment was comprised of 40 fruits per replication. Fruit samples, each comprising of 9 fruits, were drawn from each treatment at 3, 6, 9 and 12 days of storage for physicochemical analysis. Following observations were made to find out the impact of AA application on the quality of stored guava fruits.

\subsection{Determination of Physiologicals and Biochemcials Variables}

Physiological weight loss (PWL) was calculated by weighing 10 fruits per treatment on digital balance (PTL, RX 5000, Japan) before and after storage (Waskar et al., 1999). PWL was calculated according to the formula as given below.

Physiological weight $\operatorname{loss}(\%)=\frac{\text { Weight before storage-weight after storage }}{\text { Weight before storage }} \times 100$.

Similarly, fruit decay percentage was estimated by taking the ratio between number of decayed fruit and total number of fruit.

An advanced refractometer (ATAGO, RS-5000, Atago, Japan) was utilized to gauge soluble solid content (SSC) of fruit juice. The TA of fruit juice was analyzed as suggested by (Hortwitz, 1960). Distilled water and $0.1 \mathrm{~N} \mathrm{NaOH}$ was used for dilution of fruit juice for titration, using 2-3 drops of phenolphthalein as an indicator. To calculate the SSC: TA ratio the percentage of SSC was divided with the percentage of the TA.

Digital pH meter was used to determine the $\mathrm{pH}$ (HI 98107, Hanna Instruments, Mauritius). Vitamin C contents were measured from guava juice following the previously described method by (Hortwitz, 1975). Fruit juice was filtered and titrated using 2, 6-dichlorophenolindophenol dye to light pink color as end point following the dilution with $0.4 \%$ oxalic acid solution. For sugar analysis, guava fruit pulp (10 g) was added to $100 \mathrm{~mL}$ distilled water $(25 \mathrm{~mL} 25 \%$ lead acetate solution and $10 \mathrm{~mL} 20 \%$ potassium oxalate) followed by filteration of solution. The filtrate was used to determine total sugars and were expressed as percentage. Measurement of total phenolic contents from guava pulp were quantified by the method proposed by (Ainsworth \& Gillespie, 2007). Gallic acid was used as standard and their concentration was expressed on fresh weight basis $\mathrm{mg} \mathrm{Kg}^{-1}$. Standard used in this study was gallic acid its concentration was presented on fresh weight basis.

\subsection{Determination of SOD, POD and CAT Enzymes activities}

Fruit pulp (10 g) was homogenized in $25 \mathrm{~mL}$ of ice-cold extraction buffer and 0.5 g polyvinyl polypyrrolidone (PVPP). Extraction buffer for SOD, CAT assays (50 mM sodium phosphate with $\mathrm{pH} 7.8$ ) and for POD (100 mM sodium phosphate buffer with $\mathrm{pH} 6.4)$ were used. The homogenate was centrifuged $\left(27,000 \times \mathrm{g}\right.$ for $50 \mathrm{~min}$ at $\left.4{ }^{\circ} \mathrm{C}\right)$ and the resulting supernatants were used directly for assay. SOD enzyme was determined as described by (Liu et al., 2014). Briefly, $3 \mathrm{~mL}$ reaction mixture (65 mM sodium phosphate buffer ( $\mathrm{pH} 7.8$ ), $13 \mathrm{mM}$ methionine, $75 \mu \mathrm{M}$ NBT, $10 \mu \mathrm{M}$ EDTA, $2 \mu \mathrm{M}$ riboflavin) and $0.1 \mathrm{~mL}$ of the enzyme extract were used for SOD activity. The mixtures were illuminated to light $\left(60 \mathrm{~mol} \mathrm{~m}^{-2} \mathrm{~s}^{-1}\right)$ for $10 \mathrm{~min}$ and the absorbance was noted at $560 \mathrm{~nm}$. Identical solution held in the dark served as blank. Finally, SOD activity was expressed $\mathrm{Ug}^{-1} \mathrm{~min}^{-1} \mathrm{FW}$. POD enzyme was determined as described by (Ali et al., 2016). Briefly, a reaction mixture (100 mM sodium phosphate buffer with $\mathrm{pH} 6.4$ ), $8 \mathrm{mM}$ guaiacol) was prepared and $100 \mu \mathrm{L}$ enzyme extract was incubated at $30{ }^{\circ} \mathrm{C}$ and added with $\mathrm{H}_{2} \mathrm{O}_{2}$. Finally, the absorbance was determined at $460 \mathrm{n}$, and enzyme activity was expressed as $\mathrm{Ug}^{-1} \mathrm{~min}^{-1} \mathrm{FW}$.

CAT enzyme activity was determined as method proposed recently by (Liu et al., 2014). Briefly, $1.9 \mathrm{~mL}$ reaction solution ( $50 \mathrm{mM}$ sodium phosphate buffer with $\mathrm{pH}$ 7, $1 \mathrm{~mL} 40 \mathrm{mM} \mathrm{H}_{2} \mathrm{O}_{2}$ ) and $0.1 \mathrm{~mL}$ enzyme extract was used for CAT activity. About $200 \mu \mathrm{L}$ from the above solution was placed in the 96 well plate and absorbance was taken at $240 \mathrm{~nm}$ and enzyme activity was expressed as $\mathrm{Ug}^{-1} \mathrm{~min}^{-1} \mathrm{FW}$.

\subsection{Statistical analysis}

Data was subjected to analysis of variance using two factorial completely randomized design (CRD) with Statistix $-8.1^{\oplus}$ software (Analytical Software, Tallahassee, USA). Comparison of Least significant differences among treatments mean was executed by using Fishers test $(\mathrm{P}<0.05)$. 


\section{Results and discussion}

The results of physiological and chemical analysis of guava fruits (cv. Golla) after harvest during storage at ambient conditions are shown below. Physiological weight loss (PWL) of guava fruits increased in all treatments with the progression of storage periods. PWL exhibited linear increasing trend during entire 12 days of storage (Figure 1A). Application of AA significantly ( $\mathrm{p} \leq 0.05$ ) retarded the PWL of guava fruits during storage compared to untreated fruits. The lowest PWL was found in 200 ppm AA-treated fruits, while highest PWL was observed in untreated fruits after 12 days of storage (Figure 1A). AA and its derivates have been used as an antioxidant and anti-browning agent in edible coatings to retain postharvest quality of fresh-cut fruits and vegetables (Tapia et al., 2008; Xing et al., 2010). The results revealed that PWL increased during storage days, which might be due to increase in respiration rate from fruits. PWL decreased significantly all treatments thought the storage periods, likewise, results have been recorded in apple fruits treated with $1 \%$ chitosan $+2 \%$ AA showed decline in weight loss than control fruits (Qi et al., 2011).

Fruit decay (FD) continuously increased in untreated fruits as compared to AA-treated guava fruits with progress of storage conditions (Figure 1B). AA-treated fruits showed significantly $(\mathrm{P} \leq 0.05)$ less fruit decay as compared with untreated fruits. However, decay percentage of untreated fruits was 2.27 times higher, then fruits treated with 200 ppm AA after $12 \mathrm{~d}$ of storage (Figure 1B). Our findings are similar to that found by Puthmee et al., (2009), which obtained postharvest treatment of fresh-cut mangoes with $1.5 \%$ AA reduces weight loss, change in color and microbial decay.

Regardless of the treatments, SSC of guava fruits increased slowly during storage periods (Table 1). SSC in AA treated samples were lower than untreated guava fruits during storage periods. SSC was increased gradually in all treatments, however, higher level was noticed in untreated fruits $(9.96 \%)$, while lower level was found in 200 ppm AA treated fruits (8.27\%) during the $12 \mathrm{~d}$ of storage (Table 1). Silva et al. (2018) obtained approximately $8 \pm 1.5 \%$ SSC in moderately ripe or ripe guava fruits which also showed gradual increase during storage. AA treated fruits significantly reduced the SSC contents than control. Similarly, SSC content were recorded lower in 300 ppm AA treated fruits of 'Umran' ber at room temperature (Siddiqui \& Gupta, 1995). $\mathrm{AA}+$ Aloe vera combination stabilized SSC content during first 12 days of storage and thereafter cause a slight increase in subsequent storage days (Sogvar et al., 2016).

The changes in TA contents were shown in the Table 1. TA contents continuously reduced regardless of treatments during entire storage time. However, TA contents found higher in AA treated samples as compare with control during all storage time. TA in 200 ppm AA treated fruit was higher (0.47\%) than untreated fruits $(0.32 \%)$ as shown in Table 1 . According to Echeverria \& Valich, (1989) alteration in fruit metabolism results in depletion of organic acids during respiration caused TA contents to decrease during storage. Arowora et al. (2013) found that ascorbic acid application might inhibit the uptake of oxygen during fruit metabolic process, which as result reduced the respiration rate. Sogvar et al. (2016) also observed that decline in TA was lower in AA treated fruits, while recorded higher in untreated fruits of guava, plum and ber

All treatments showed a gradual increasing trend for SSC: TA ratio with the increase in storage days (Table 1$)$. However, in control ratio of SSC: TA was significantly $(P<0.05 \%)$ higher, than all AA treatments during the all the storage interval. On $12 \mathrm{~d}$ of storage, 200 ppm AA showed significantly lowest SSC: TA ratio (1.34-times) than control fruit as shown in Table 1. Increasing the AA levels led to decrease in SSC: TA ratio. Similar finding has been reported by Ali et al., (2016), which showed significantly lower SSC: TA ratio in treated litchi fruits than control during cold storage.

There was slight changes in $\mathrm{pH}$ value for AA-treated and untreated fruits during the $12 \mathrm{~d}$ of storage are shown in Table 1. Regardless of treatments, $\mathrm{pH}$ values slightly increased during storage periods. On an average, the data indicated that $\mathrm{pH}$ was registered higher in untreated fruits and lower for AA-treatments with the progression of storage period (Table 1). Phebe \& Ong (2010) found that low $\mathrm{pH}$ in fruits indicated in 1-MCP treated guava fruits which delayed the senescence than control fruits.
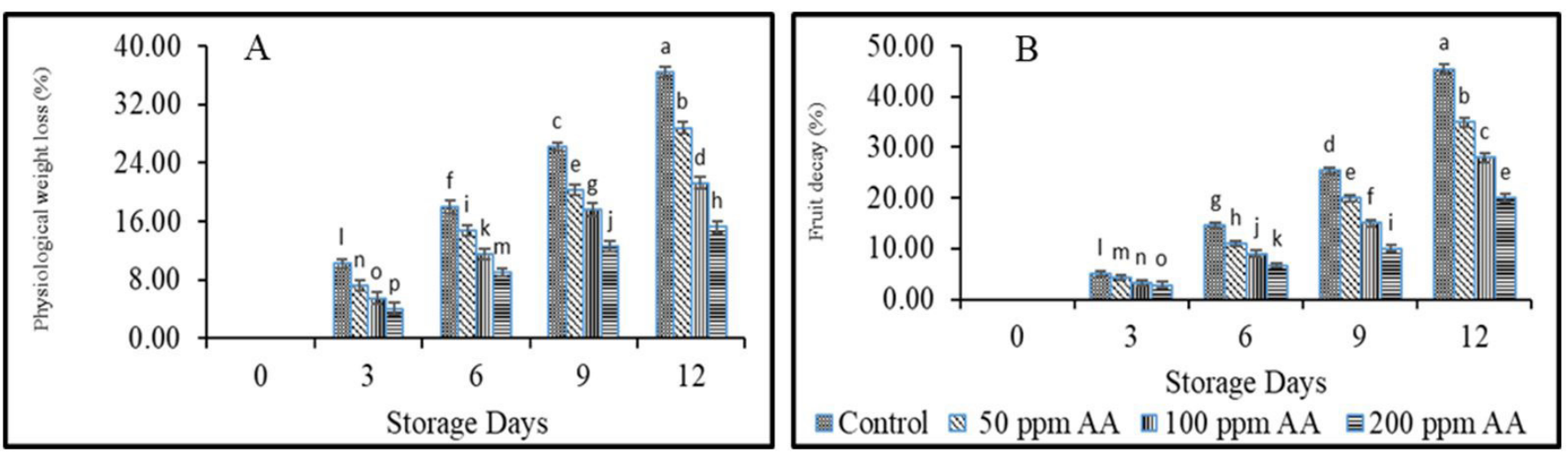

Figure 1. Effect of postharvest application of AA on physiological weight loss (A) and fruit decay (B) of guava fruit during storage at $25^{\circ} \mathrm{C}$ for 12 days. Mean values in graph with Different letter are significantly different by Fisher's least significant (LSD) test (P $\leq 0.05 \%)$. Vertical bars indicate standard error, and each value is the mean of three replicates. 
Table 1. Effect of postharvest application of AA on soluble sugar content (SSC), total acidity (TA), sugar/acid ratio (SSC: TA) and pH of guava fruit during storage at $25^{\circ} \mathrm{C}$ for 12 days.

\begin{tabular}{|c|c|c|c|c|c|c|}
\hline \multirow{2}{*}{ Attributes } & \multirow{2}{*}{$\begin{array}{l}\text { Ascorbic acid } \\
\quad(p p m)\end{array}$} & \multicolumn{5}{|c|}{ Storage days } \\
\hline & & 0 & 3 & 6 & 9 & 12 \\
\hline \multirow{3}{*}{ SSC (\%) } & 0 & $7.3 \pm 0.15 \mathrm{o}$ & $8.15 \pm 0.18 \mathrm{k}$ & $8.99 \pm 0.16 c$ & $9.21 \pm 0.13 b$ & $9.69 \pm 0.16 \mathrm{a}$ \\
\hline & 100 & $7.3 \pm 0.15 \mathrm{o}$ & $7.52 \pm 0.14 \mathrm{~m}$ & $8.35 \pm 0.11 \mathrm{~h}$ & $8.47 \pm 0.17 \mathrm{~g}$ & $8.90 \pm 0.21 \mathrm{~d}$ \\
\hline & 200 & $7.3 \pm 0.15 \mathrm{o}$ & $7.37 \pm 0.20 \mathrm{n}$ & $8.05 \pm 0.19 j$ & $8.18 \pm 0.20 \mathrm{i}$ & $8.27 \pm 0.19 \mathrm{~g}$ \\
\hline \multirow{4}{*}{$\mathrm{TA}(\%)$} & 0 & $0.71 \pm 0.004 \mathrm{a}$ & $0.58 \pm 0.002 \mathrm{~d}$ & $0.51 \pm 0.004 \mathrm{~g}$ & $0.45 \pm 0.003 \mathrm{a}$ & $0.32 \pm 0.002 \mathrm{~m}$ \\
\hline & 50 & $0.71 \pm 0.003 \mathrm{a}$ & $0.61 \pm 0.003 \mathrm{c}$ & $0.54 \pm 0.003 \mathrm{~h}$ & $0.51 \pm 0.002 b$ & $0.37 \pm 0.0031$ \\
\hline & 100 & $0.71 \pm 0.004 \mathrm{a}$ & $0.62 \pm 0.002 c$ & $0.57 \pm 0.003 \mathrm{e}$ & $0.53 \pm 0.003 c$ & $0.40 \pm 0.004 \mathrm{k}$ \\
\hline & 200 & $0.71 \pm 0.004 \mathrm{a}$ & $0.68 \pm 0.003 b$ & $0.62 \pm 0.004 \mathrm{c}$ & $0.57 \pm 0.004 \mathrm{f}$ & $0.46 \pm 0.005 j$ \\
\hline \multirow{2}{*}{ SSC: TA (ratio) } & 100 & $10.28 \pm 0.20 \mathrm{n}$ & $12.12 \pm 0.191$ & $14.64 \pm 0.19 \mathrm{hi}$ & $15.68 \pm 0.19 \mathrm{gh}$ & $22.25 \pm 0.22 c$ \\
\hline & 200 & $10.28 \pm 0.19 \mathrm{n}$ & $11.38 \pm 0.17 \mathrm{~m}$ & $13.66 \pm 0.16 \mathrm{j}$ & $14.82 \pm 0.16 \mathrm{i}$ & $19.58 \pm 0.19 \mathrm{e}$ \\
\hline \multirow{4}{*}{$\mathrm{pH}$} & 0 & $2.69 \pm 0.010 \mathrm{q}$ & $2.88 \pm 0.010 \mathrm{~m}$ & $3.39 \pm 0.020 \mathrm{i}$ & $3.71 \pm 0.030 \mathrm{a}$ & $3.65 \pm 0.040 \mathrm{c}$ \\
\hline & 50 & $2.69 \pm 0.020 \mathrm{q}$ & $2.86 \pm 0.030 \mathrm{n}$ & $3.32 \pm 0.010 \mathrm{j}$ & $3.68 \pm 0.020 b$ & $3.51 \pm 0.030 \mathrm{f}$ \\
\hline & 100 & $2.69 \pm 0.030 \mathrm{q}$ & $2.85 \pm 0.020 \mathrm{o}$ & $3.12 \pm 0.040 \mathrm{k}$ & $3.63 \pm 0.010 \mathrm{~d}$ & $3.47 \pm 0.020 \mathrm{~g}$ \\
\hline & 200 & $2.69 \pm 0.020 \mathrm{q}$ & $2.81 \pm 0.040 \mathrm{p}$ & $3.01 \pm 0.0301$ & $3.53 \pm 0.030 \mathrm{e}$ & $3.41 \pm 0.030 \mathrm{~h}$ \\
\hline
\end{tabular}

Different lettering within column shows significant differentness in mean values by Fisher's least significant $(\mathrm{LSD})$ test $(P<0.05 \%)$. Each value is the mean of three replicates

Kumar et al. (2012) observed higher $\mathrm{pH}$ due to decline in acidity in fruit juice, and guava has low $\mathrm{pH}$ due to high in organic acids.

The changes in total sugar (TS) for AA-treated and control during storage are shown in Table 2. TS were found increased in AA-treated fruits and control fruits up to $9 \mathrm{~d}$ of storage, thereafter declined slowly. However, TS contents was greater $(6.33 \%)$ in $200 \mathrm{ppm}$ AA treated fruits than untreated fruits $(5.75 \%)$ on $12 \mathrm{~d}$ of storage. (Table 2). Our results are consistent with the previous findings that different postharvest chemicals (calcium compounds, $\mathrm{GA}_{3}$ ) increased TS in guava fruits as compared with control during storage periods (Mahajan et al., 2017). It has been reported that increase in TS attributed to the fast disintegration of starch into sugar causing no further increase in TS indicating that organic serve as substrate during respiration (Javed et al., 2016; Mahajan et al., 2017; Wills et al., 1980).

In all treatments vitamin $C$ gradually declines during the storage (Table 2). Nevertheless, the rate of decline in vitamin C were significantly higher in control as compared to AA treatments. On $12 \mathrm{~d}$ of storage, $200 \mathrm{ppm}$ AA-treated fruits $(123.34 \mathrm{mg} / 100 \mathrm{~g}$ ) showed higher vitamin $C$ than control $(101.88 \mathrm{mg} / 100 \mathrm{~g})$ as shown in Table 2. The reduction in vitamin C loss might be due to low oxygen availability that delays the harmful oxidation reaction of AA in food products (Tapia et al., 2008). Our results are similar with Xing et al., (2010), which reports increase in biosynthesis or reduction in breakdown of vitamin $\mathrm{C}$ might have resulted in low rate of decline in AA treated fruits under storage.

TPC gradually decreased regardless of treatments during entire course of storage period. AA-treated fruits showed higher level of TPC, relative to control, at all sampling times. TPC contents found approximately 1.5 fold higher in $200 \mathrm{ppm} \mathrm{AA-treated}$ fruit $(75.23 \mathrm{mg} / \mathrm{kg})$, as compared with control $(45.33 \mathrm{mg} / \mathrm{kg}$ ) on $12 \mathrm{~d}$ of storage (Table 2). Singh \& Pal (2008) observed that ascorbic acid treated guava fruits have higher TPC contents during storage. Vishwasrao \& Ananthanarayan (2016) also obtained that TPC were found higher in HPMC-based edible coated fruits than uncoated guava fruits TPC were found higher at the harvest time then decline to lower limits during storage of guava fruits (Mahajan et al., 2017).

\subsection{Effect of AA on SOD, POD and CAT Enzyme Activities}

Regardless of the treatments, SOD activity increased first, then linearly decreased in guava fruits during storage periods. AA-treated fruits showed relatively higher SOD activity than untreated fruit during entire storage durations (Figure 2A). SOD activities significantly $(\mathrm{P} \leq 0.05 \%)$ rose slowly as the AA levels increased than control. At $12 \mathrm{~d}$ of storage, SOD activity was 1.4-fold higher in $200 \mathrm{ppm}$ AA-treated fruits, compared with control. Likewise, compared with control, $100 \mathrm{ppm}$ AA and $50 \mathrm{ppm}$ 
Table 2. Effect of postharvest application of AA on total sugars (TS), Vitamin C contents (Vit. C) and total phenolic contents (TPC) of guava fruit during storage at $25^{\circ} \mathrm{C}$ for 12 days.

\begin{tabular}{|c|c|c|c|c|c|c|}
\hline \multirow{2}{*}{ Attributes } & \multirow{2}{*}{$\begin{array}{l}\text { Ascorbic acid } \\
(\mathrm{ppm})\end{array}$} & \multicolumn{5}{|c|}{ Storage days } \\
\hline & & 0 & 3 & 6 & 9 & 12 \\
\hline \multirow{4}{*}{ TS (\%) } & 0 & $5.70 \pm 0.19 \mathrm{n}$ & $5.80 \pm 0.201$ & $5.95 \pm 0.18 \mathrm{~h}$ & $5.85 \pm 0.17 \mathrm{k}$ & $5.75 \pm 0.14 \mathrm{~m}$ \\
\hline & 50 & $5.70 \pm 0.19 \mathrm{n}$ & $5.85 \pm 0.19 \mathrm{k}$ & $6.02 \pm 0.17 \mathrm{~g}$ & $6.10 \pm 0.16 \mathrm{f}$ & $5.90 \pm 1.16 \mathrm{j}$ \\
\hline & 100 & $5.71 \pm 0.18 \mathrm{n}$ & $5.92 \pm 0.16 \mathrm{i}$ & $6.10 \pm 0.21 \mathrm{f}$ & $6.50 \pm 0.22 b$ & $6.23 \pm 0.18 \mathrm{~d}$ \\
\hline & 200 & $5.70 \pm 0.16 \mathrm{n}$ & $5.96 \pm 0.13 \mathrm{~h}$ & $6.21 \pm 0.19 \mathrm{e}$ & $6.75 \pm 0.21 \mathrm{a}$ & $6.33 \pm 0.20 c$ \\
\hline \multirow{4}{*}{ Vit C (mg/100 g) } & 0 & $218.00 \pm 2.54 \mathrm{a}$ & $195.8 \pm 2.45 \mathrm{e}$ & $152.49 \pm 3.06 \mathrm{i}$ & $125.85 \pm 3.351$ & $101.88 \pm 2.29 \mathrm{p}$ \\
\hline & 50 & $218.00 \pm 2.51 \mathrm{a}$ & $200.58 \pm 3.01 \mathrm{~d}$ & $158.57 \pm 3.26 \mathrm{~h}$ & $130.69 \pm 2.87 \mathrm{k}$ & $106.73 \pm 3.74 \mathrm{o}$ \\
\hline & 100 & $218.00 \pm 2.78 \mathrm{a}$ & $205.42 \pm 2.84 \mathrm{c}$ & $163.68 \pm 2.98 \mathrm{~g}$ & $135.77 \pm 3.05 \mathrm{j}$ & $112.50 \pm 3.16 \mathrm{n}$ \\
\hline & 200 & $218.00 \pm 2.64 \mathrm{a}$ & $210.98 \pm 3.21 b$ & $178.75 \pm 3.07 \mathrm{f}$ & $149.65 \pm 2.64 \mathrm{i}$ & $123.34 \pm 3.34 \mathrm{~m}$ \\
\hline \multirow{4}{*}{ TPC (mg/kg) } & 0 & $181.66 \pm 2.14 \mathrm{a}$ & $135.73 \pm 2.89 \mathrm{e}$ & $98.88 \pm 2.84 \mathrm{i}$ & $60.47 \pm 2.85 \mathrm{n}$ & $45.33 \pm 2.54 \mathrm{p}$ \\
\hline & 50 & $180.16 \pm 2.14 \mathrm{a}$ & $145.7 \pm 2.54 \mathrm{~d}$ & $109.65 \pm 3.84 \mathrm{~h}$ & $77.47 \pm 2.451$ & $54.33 \pm 3.01 \mathrm{o}$ \\
\hline & 100 & $180.56 \pm 2.13 \mathrm{a}$ & $154.03 \pm 2.01 \mathrm{c}$ & $118.78 \pm 2.89 \mathrm{~g}$ & $85.47 \pm 3.15 \mathrm{k}$ & $62.93 \pm 2.98 n$ \\
\hline & 200 & $181.86 \pm 2.15 \mathrm{a}$ & $163.53 \pm 2.85 b$ & $132.95 \pm 4.08 \mathrm{f}$ & $95.4 \pm 2.54 \mathrm{j}$ & $75.23 \pm 2.64 \mathrm{~m}$ \\
\hline
\end{tabular}

Mean values with different letter are significantly different by Fisher's least significant (LSD) test $(\mathrm{P}<0.05 \%)$. Each value is the mean of three replicates.
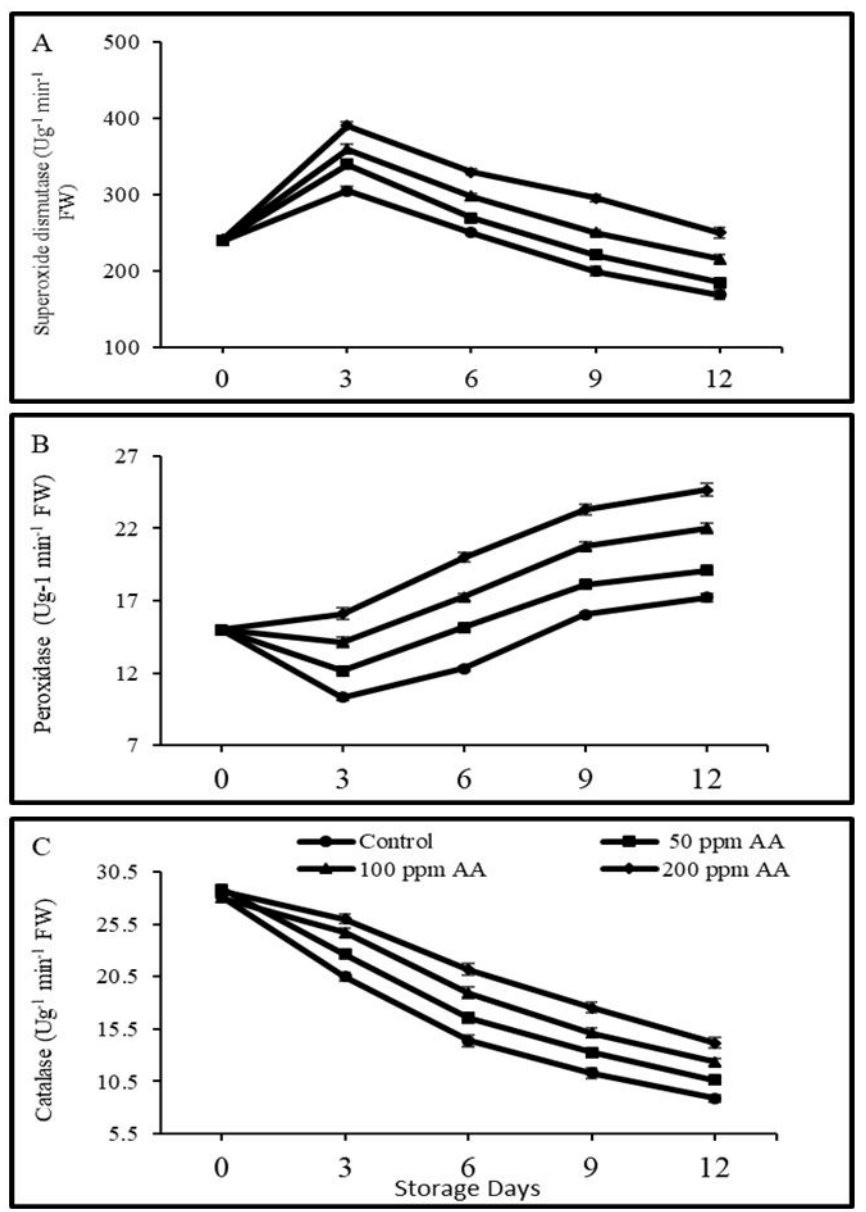

Figure 2. Effect of postharvest application of AA on activities of superoxide dismutase (A), peroxidase (B), and catalase (C) of guava fruit during storage at $25^{\circ} \mathrm{C}$ for 12 days. Each value is the mean of three replicates, and vertical bars indicated standard errors.
AA-treated fruits showed 1.27 and 1.09-time greater SOD activity after $12 \mathrm{~d}$ of storage, respectively. (Figure $2 \mathrm{~A}$ ). The changes in POD activity decreased first, then linearly increased during storage periods, in all treatments (Figure 2B). Nevertheless, AA-treated fruits showed relatively higher $\mathrm{POD}$ activity during storage than control. Likewise, $200 \mathrm{ppm} \mathrm{AA}$ and $100 \mathrm{ppm}$ AA treated fruits showed greater $\mathrm{POD}$ activity which was 1.43-time and 1.27 time higher, after $12 \mathrm{~d}$ of storage than untreated fruits, respectively (Figure 2B). Regardless of treatments, activity of CAT showed gradual decrease during storage phase. However, CAT activity declined noticeably in control than AA-treated fruits. Likewise, 200 ppm AA-treated fruits showed 1.59-flods higher CAT activity than control, after $12 \mathrm{~d}$ of storage. (Figure 2C).

Generally, antioxidant defense-enzymes (SOD, POD, and CAT) are considered of great potential for scavenging ROS and, therefore, play a key role in maintaining fruit postharvest quality. In our study, SOD, POD and CAT enzymes tended to have higher activity in AA-treated guava fruits than control, which is consistent with Lin et al. (2007), who reported higher enzymatic activities as well as also found lower concentration of $\mathrm{H}_{2} \mathrm{O}_{2}$ and less lipid peroxidation. Decrease in decay incidence, reduction in enzymatic activities of SOD, POD and CAT that hinders antioxidant compounds might be associated with capacity of AA to retain fruit quality (Sogvar et al., 2016). However, the molecular mechanism involved in AA enhancing enzyme activities and TPC is unknown and should be explored further.

\section{Conclusions}

Guava is highly perishable fruit and less work was conducted on the shelf life and postharvest. In this study four concentrations of AA were evaluated on physiochemical and enzymatic changes in guava $\mathrm{cv}$. Golla for $12 \mathrm{~d}$ of storage at ambient storage conditions. Our results showed that 200 ppm AA application 
significantly reduce weight loss, decay percentage, increased SSC, TA, TS, Vitamin C, and TPC, and decreased $\mathrm{pH}$ and SSC: TA ratio of guava fruits during ambient storage. Meanwhile, AA application significantly delayed SOD, POD, and CAT activities, thus reducing oxidative stress. Over all the quality of guava fruits were maintained by application of ascorbic acid during storage as compared to untreated fruits. Our results suggest that ascorbic acid effectively improves the quality attributes and maintained activities of antioxidative enzymes in guava fruits, and would be feasible for guava storage on a commercial use.

\section{Acknowledgements}

The research work was supported by Institute of Horticultural Sciences, University of Agriculture, Faisalabad. Pakistan

\section{References}

Ainsworth, E. A., \& Gillespie, K. M. (2007). Estimation of total phenolic content and other oxidation substrates in plant tissues using FolinCiocalteu reagent. Nature Protocols, 2(4), 875-877. http://dx.doi. org/10.1038/nprot.2007.102. PMid:17446889.

Ali, S., Khan, A. S., \& Malik, A. U. (2016). Postharvest L-cysteine application delayed pericarp browning, suppressed lipid peroxidation and maintained antioxidative activities of litchi fruit. Postharvest Biology and Technology, 121, 135-142. http://dx.doi.org/10.1016/j. postharvbio.2016.07.015.

Arowora, K., Williams, J., Adetunji, C., Fawole, O., Afolayan, S., Olaleye, O., Ogundele, B. (2013). Effects of Aloe vera coatings on quality characteristics of oranges stored under cold storage. Greener Journal of Agricultural Sciences, 3(1), 39-47. https://doi.org/10.15580/ gjas.2013.1.110112192.

Echeverria, E., \& Valich, J. (1989). Enzymes of sugar and acid metabolism in stored 'Valencia' oranges. Journal of the American Society for Horticultural Science, 114(3), 445-449.

Gill, K., Dhaliwal, H., Mahajan, B., Paliyath, G., \& Boora, R. (2016). Enhancing postharvest shelf life and quality of guava (Psidium guajava L.) cv. Allahabad Safeda by pre-harvest application of hexanal containing aqueous formulation. Postharvest Biology and Technology, 112, 224-232. http://dx.doi.org/10.1016/j. postharvbio.2015.09.010.

Gutiérrez, R. M. P., Mitchell, S., \& Solis, R. V. (2008). Psidium guajava: A review of its traditional uses, phytochemistry and pharmacology. Journal of Ethnopharmacology, 117(1), 1-27. http://dx.doi.org/10.1016/j. jep.2008.01.025. PMid:18353572.

Hortwitz, W. (1960). Official and tentative methods of analysis Association of the Official Agriculture Chemist (vol. 9, pp. 320-341). Washington, DC: AOAC.

Hortwitz, W. (1975). Official and tentative methods of analysis (Vol. 9, p. 320-341). Washington, DC: Association of the Official Agriculture Chemist. https://doi.org/10.1001/jama.1937.02780200064037.

Javed, M. S., Randhawa, M. A., Butt, M. S., \& Nawaz, H. (2016). Effect of calcium lactate and modified atmosphere storage on biochemical characteristics of guava fruit. Journal of Food Processing and Preservation, 40(4), 657-666. http://dx.doi. org/10.1111/jfpp.12645.

Kumar, S. S., Sreenivas, K., Shankarappa, T., \& Ravindra, V. (2012). Standardization of recipe for value added nutraceutical beverage of guava blended with Aloe vera and roselle. Journal of Ecology and Environment, 30, 995-1001.
Lin, L., Li, Q., Wang, B., Cao, J., \& Jiang, W. (2007). Inhibition of core browning in 'Yali'pear fruit by post-harvest treatment with ascorbic acid. The Journal of Horticultural Science \& Biotechnology, 82(3), 397-402. http://dx.doi.org/10.1080/14620316.2007.11512250.

Liu, K., Yuan, C., Chen, Y., Li, H., \& Liu, J. (2014). Combined effects of ascorbic acid and chitosan on the quality maintenance and shelf life of plums. Scientia Horticulturae, 176, 45-53. http://dx.doi. org/10.1016/j.scienta.2014.06.027.

Mahajan, B. V. C., Gill, K. S., \& Dhaliwal, H. S. (2017). Effect of storage period on various physiological, biochemical and enzymatic parameters of guava (Psidium guajava L.) fruit. Journal of Experimental Biology and Agricultural Sciences, 5(6), 846-851. http://dx.doi. org/10.18006/2017.5(6).846.851.

McCook-Russell, K. P., Nair, M. G., Facey, P. C., \& Bowen-Forbes, C. S. (2012). Nutritional and nutraceutical comparison of Jamaican Psidium cattleianum (strawberry guava) and Psidium guajava (common guava) fruits. Food Chemistry, 134(2), 1069-1073. http:// dx.doi.org/10.1016/j.foodchem.2012.03.018. PMid:23107729.

Murmu, S. B., \& Mishra, H. N. (2017). Engineering evaluation of thickness and type of packaging materials based on the modified atmosphere packaging requirements of guava (Cv. Baruipur). LWT, 78, 273-280. http://dx.doi.org/10.1016/j.lwt.2016.12.043.

Olajide, O., Awe, S., \& Makinde, J. (1999). Pharmacological studies on the leaf of Psidium guajava. Fitoterapia, 70(1), 25-31. http://dx.doi. org/10.1016/S0367-326X(98)00010-0.

Oms-Oliu, G., Rojas-Graü, M. A., González, L. A., Varela, P., SolivaFortuny, R., Hernando, M. I. H., \& Martín-Belloso, O. (2010). Recent approaches using chemical treatments to preserve quality of fresh-cut fruit: A review. Postharvest Biology and Technology, 57(3), 139-148. http://dx.doi.org/10.1016/j.postharvbio.2010.04.001.

Pandey, S., Joshua, J. E., Bisen, \& Abhay, (2010). Influence of gammairradiation, growth retardants and coatings on the shelf life of winter guava fruits (Psidium guajava L.). Journal of Food Science and Technology, 47(1), 124-127. http://dx.doi.org/10.1007/s13197010-0007-3. PMid:23572614.

Phebe, D., \& Ong, P. (2010). Extending 'Kampuchea'guava shelf-life at $27 \mathrm{oC}$ using 1-methylcyclopropene. International Food Research Journal, 17(3), 63-69. http://dx.doi.org/10.17660/actahortic.2005.671.46.

Puthmee, T., Boonyaritthongchai, P., \& Kanlayanarat, S. (2009, August 3-5). Effect of ascorbic acid on shelf-life and quality of fresh cut'Mahachanok'mango. Paper presented at the Southeast Asia Symposium on Quality and Safety of Fresh and Fresh-Cut Produce. Bangkok, Thailand: King Mongkut's University of Technology.

Qi, H., Hu, W., Jiang, A., Tian, M., \& Li, Y. (2011). Extending shelflife of fresh-cut 'Fujiapples with chitosan-coatings. Innovative Food Science \& Emerging Technologies, 12(1), 62-66. http://dx.doi. org/10.1016/j.ifset.2010.11.001.

Rana, S., \& Siddiqui, S. (2018). Comparative effect of different individual wrappings on shelf life of guava (Psidium guajava). Journal of Food Science and Technology, 55(8), 2935-2944. http://dx.doi.org/10.1007/ s13197-018-3211-1. PMid:30065402.

Siddiqui, S., \& Gupta, O. (1995). Effect of post harvest application of some chemicals on the shelf life of ber (Zizyphus mauritiana Lamk) fruits. Haryana Journal of Horticultural Sciences, 24, 19-19. http:// dx.doi.org/10.5958/2249-5258.2017.00027.6.

Silva, W. B., Silva, G. M. C., Santana, D. B., Salvador, A. R., Medeiros, D. B., Belghith, I., \& Misobutsi, G. P. (2018). Chitosan delays ripening and ROS production in guava (Psidium guajava L.) fruit. Food Chemistry, 242, 232-238. http://dx.doi.org/10.1016/j.foodchem.2017.09.052. PMid:29037684. 
Singh, S., \& Pal, R. (2008). Response of climacteric-type guava (Psidium guajava L.) to postharvest treatment with 1-MCP. Postharvest Biology and Technology, 47(3), 307-314. http://dx.doi.org/10.1016/j. postharvbio.2007.08.010.

Sogvar, O. B., Saba, M. K., \& Emamifar, A. (2016). Aloe vera and ascorbic acid coatings maintain postharvest quality and reduce microbial load of strawberry fruit. Postharvest Biology and Technology, 114, 29-35. http://dx.doi.org/10.1016/j.postharvbio.2015.11.019.

Tapia, M., Rojas-Graü, M., Carmona, A., Rodríguez, F., Soliva-Fortuny, R., \& Martin-Belloso, O. (2008). Use of alginate-and gellan-based coatings for improving barrier, texture and nutritional properties of fresh-cut papaya. Food Hydrocolloids, 22(8), 1493-1503. http:// dx.doi.org/10.1016/j.foodhyd.2007.10.004.

Teixeira, G. H., Júnior, L. C. C., Ferraudo, A. S., \& Durigan, J. F. (2016). Quality of guava (Psidium guajava L. cv. Pedro Sato) fruit stored in low-O2 controlled atmospheres is negatively affected by increasing levels of CO2. Postharvest Biology and Technology, 111, 62-68. http:// dx.doi.org/10.1016/j.postharvbio.2015.07.022.

Vishwasrao, C., \& Ananthanarayan, L. (2016). Postharvest shelf-life extension of pink guavas (Psidium guajava L.) using HPMC-based edible surface coatings. Journal of Food Science and Technology, 53(4), 19661974. http://dx.doi.org/10.1007/s13197-015-2164-x. PMid:27413223.
Waskar, D. P., Kheldar, R. M., \& Garande, V. K. (1999). Effect of postharvest treatment on the shelf life and quality of pomegranate in evaporative cooling chamber and ambient conditions. Journal of Food Science and Technology, 2, 114-117.

Watson, L., \& Dallwitz, M. J. (1991). The families of angiosperms: Automated descriptions, with interactive identification and information retrieval. Australian Systematic Botany, 4(4), 681-695. http://dx.doi.org/10.1071/SB9910681.

Wills, R. B. H., Bambridge, P., \& Scott, K. J. (1980). Use of flesh firmness and other objective tests to determine consumer acceptability of Delicious apples. Australian Journal of Experimental Agriculture, 20(103), 252-256. http://dx.doi.org/10.1071/EA9800252.

Xing, Y., Li, X., Xu, Q., Jiang, Y., Yun, J., \& Li, W. (2010). Effects of chitosan-based coating and modified atmosphere packaging (MAP) on browning and shelf life of fresh-cut lotus root (Nelumbo nucifera Gaerth). Innovative Food Science \& Emerging Technologies, 11(4), 684-689. http://dx.doi.org/10.1016/j.ifset.2010.07.006.

Yurdugül, S. (2016). Effects of edible coating-Semperfresh ${ }^{\mathrm{ns}}$, ascorbic acid and whey protein treatment on certain microbiological, physical and chemical qualities of peeled bananas "Musa sapientum". Bulgarian Journal of Agricultural Science, 22, 647-654. 